\title{
ON THE COMMON ORIGIN OF SOUTHEAST ASIA OF PHYTOPLASMA ASSOCIATED DISEASES OF COCONUT
}

\author{
BY \\ Hugh C Harries ${ }^{1}$
}

\section{INTRODUCHON}

The association of phytoplasma with two wilt diseases of coconut in Indonesia might be seen as a threat to the Asian and Pacific regions because epidemic phytoplasma diseases of coconut in America and Africa arc spreading out of control. Yet research has already suggested that these diseases originated in the Far East where resist varieties can bc found. Recently, a workshop was held to assess lethal diseases of coconuts caused by phytoplasmas and their importance in southeast Asia. The workshop took place in Manado, North Sulawesi , Indonesia on 16-17 February 1998 and the full proceedings will be published separately. The participants beard about the situation of coconut development and the unpact of etiology of coconut wilt diseases in Indonesia. As $95 \%$ of coconuts in Indonesia are grown by small farmers the workshop was also informed of the impact of coconut diseases on small farmers. Specific reports were made on the history and status of Natuna wilt disease and the distribution of epiderniology of Kahmantan wilt diseasc. These have both been associated writh phytoplasma. Other reports were made on the development of coconut wilt discase in Kotawaringin, Timur District, Central Kalimantan Province and on the history and status of yellow disease of coconut palm in Central Sulawesi, for which no causal agents have yet been identified. Intemational representatives also spoke about root (wilt) and Tatipakka diseases of coconut in India and declffie diseases of coconut in Sri Lanka that have not been associated with phytoplasma and on lethal diseases in America and Africa that arc associated with phytoplasma. The history and biology of phytoplasmas as plant pathogens and diagnostic methods for coconut diseases; were explained in a session on the pathogen. Safe germplasm movernent for scientific purposes of conservation and exchange was dealt with and, for fanners and extension agents, the practical application of resistant local coconut varieties for replanting was advised.

By coincidence, the association of phytoplasma with Natuna Wilt and Kalimantan Wilt diseases comes just exactly 20 years after a prediction was made that the lethal yellowing type of disease would be found in the Far East. That prediction also said that outbreaks would be sporadic and non-epidemic because of the natural resistance of local coconut plantations. The first part of the prediction is now fulfilled, subject to corroboration. The second part remains to be confirmed, but is supported by early evidence.

At the time the prediction was published (Harries, 1978a), it prompted three other papers:

* a global perspective on the risk firom lethal yellowing disease (Harries 1978b);

* a suggestion for a southeast Asian location for the probable origin of lethal yellowing and for its co-identity with other lethal diseases of coconut (Chiarappa, 1979); and

* an identification of Malaysian wilt as a sporadic disease only after an LY susceptable variety was introduced from Panama (Harries, 1980).

The two titles by Harries appeared in ISBN registered publications and are only briefly mentioned here. The publication by Chiarappa had an informal circulation, restricted mainly to

\footnotetext{
${ }^{1}$ Coconut Breeder, UK
} 
organizations represented by 91 participants at the FAO $5^{\text {th }}$ Technical Working Party on Coconut Production, Protection and Processing (which was the last ever held). The Editor of CORD has kindly agreed to reproduce the text of that paper (as Appendix 1), for the benefit of modem research workers who may not otherwise have access to it. Dr. Chiarappa has kindly allowed footnotes to be added, where necessary.

\section{LETHAL DISEASES ASSOCIATED WITH PHYTOPLASMAS}

\section{Lethal yellowing in global perspective}

In Jamaica, mi the 1960s and 70s, coconut vanieties collected from many parts of the world were exposed to lethal yellowing disease over peniods of 7 to 11 years. The disease eradicated control plots of the "Jamaica Tall" variety widiin each experimental field, and entire commercial plantations mi close proximity. Replanted "Jamaica Tall" seedhngs in experimental plots also died. Many foreign varieties showed as high a rate of susceptibility as the "Jamaica Tall" . Some varieties showed an intermediate level of resistance; few showed the high degree of resistance of the 'Malayan Dwarf.'. The disease is no longer epidemic in Jamaica because it was brought under control by replanting commercial fields with the resistant 'Malayan Dwarf variety and the 'Maypan' vaniety.

Using data from the ntunerous foreign varieties in the Jamaican field exposure trials it was possible to calculate "LY loss factors" for the major coconut growing regions. From the estimated areas planted to coconut varieties predominating in those regions, a potential loss of $62 \%$ can be calculated (Table 1).

Table 1. The global threat of lethal yellowing disease of coconuts

\begin{tabular}{|l|c|c|c|}
\hline \multicolumn{1}{|c|}{ Region } & $\begin{array}{c}\text { Estimated area } \\
\%(\mathrm{a})\end{array}$ & $\begin{array}{c}\text { LY Loss } \\
\text { Factor \% (b) }\end{array}$ & $\begin{array}{c}\text { Estimated Losses } \\
\%(\mathrm{a})+(\mathrm{b})\end{array}$ \\
\hline Southeast Asia & 58.5 & 50 & 26 \\
South Asia & 24.6 & 90 & 22 \\
Pacific Islands & 7.8 & 75 & 6 \\
Africa & 4.1 & 90 & 4 \\
America & 5.0 & 80 & 4 \\
\hline Total & 100.0 & & 62 \\
\hline
\end{tabular}

(a) from Child (1974

(b) estimated from Coconut Industry Board Research reports 1967-77

\footnotetext{
${ }^{1 / N o}$ attempt has been made to update these figures. Areas may have changed since 1978 but there is no evidence that loss factors have altered.

An estimated loss thatm'volves almost two-thirds of the world's coconut is serious. For those who are complacent that the disease will never reach thern, remember that this was thought by farmers mi eastem Jamaica before 1961 and in Mexico before 1978. Farmers in Ivory Coast have been watching the inexorable westward spread of the disease in Ghana smice 1975. Certainly, for the major coconut growing countries it is not an immediate threat. However, it does raise the question of the advisability of introducing susceptible varieties into areas where they do not now occur and the suitability of certain hybrids combinations.
} 


\section{Common origin of disease and resistance}

Resistance to lethal yellowing disease also has a bearing on the identification and distribution of coconut varieties (Harries, 1978a). It was suggested that if this type of disease did. once occur in Asia, perhaps it still does. It would be a minor disease of limited extent because of resistance and perhaps because of natural control of the vector. Symptoms could easily be overlooked (Harries, 1978b). The phytopathological implications of these ideas on disease origin were soon developed. (Chirappa, $1979 \&$ Appendix 1) and subsequently the genetics of durable resistance (Harries, 1995) and the implications on genetic improvement (Ashbumer \& Been, 1997) have been considered.

The varieties; of southeast Asia, typified by those in Malaysia, are resistant, according to theory, because phytoplasma disease was once epidemic on that continental coast. Natural and human selection over a very long time accounts for the differences. Deaths would not now reach epidemic proportions because of the general level of resistance. For the same reason, symptoms would not be identical with those seen on large plantations; of very susceptible varieties. Exactly such a situation was reported in Malaysia (Sharples, 1928; Johnston, 1961) and it was subsequently suggested (Maramorosch, 1964) that Malaysian wilt is related, to lethal yellowing, with modifications caused by the reaction of resistant varieties.

\section{Caribbean coconuts in Malaysia}

In 1920/21 coconuts from the San Blas islands on the Caribbean coast of Panama (now known to be the same type as the Jamaica Tall and therefore highly susceptible to phytoplasma disease) were introduced to Lower Perak (Smith, 1932). Three lots of forty each were established in alternate rows with local talls. In 1928, just at the time those palms had become well established a coconut wilt disease was described in the Bernam River district (Sharples, 1928) and it was recorded that in somc groves 50 to 200 palms died of wilt. The Bemam River marks the southern boundary of Lower Perak. Unfortunately, there was no indication of what coconut varieties were involved but it was a sporadic disease and not an epidemic so that if San Blas were interplanted between the rows of more resistant Malayan Tall, some would have survived. San Blas palms (or their progeny) were still identifiable 50-60 years later (Smith, 1971; Harries, unpublished observation 1980) and were included in a trial to compare Malayan Dwarf x West African Tall hybrids with tall varieties (Vanialingam et al, 1975) (but data on their performance were not kept separate from the Malayan Tall).

In recent years, and an ignorance of the possibility of endemic phytoplasma diseases, seednuts of varieties now known to be susceptible to lethal yellowing and pollen from West African Tall to make dwarf $\mathrm{x}$ tall hybrids have been introduced to Indonesia, Malaysia and the Philippines. It is not suggested that any of those introductions are themselves sources of disease. They were taken from disease-free areas, quarantine precautions were observed and the disease is not known to be transmitted by seed or pollen. The point that it is intended to make is that any increase in die wnount of susceptible germplasm that is planted might increase the risk of disease outbreaks. This must not be taken as an attempt to see lethal yellowing lurking everywhere. Epidemics such as are occurring mi the Western Hemisphere now are unlikely to reappear in southeast Asia. Nevertheless, it is a subject to be kept in nuind when choosing parents for Fl hybrids and when introducing germplasm from overseas.

\section{CONCLUSION}

In making recommendations, the Manado workshop participants considered that the group of diseases posing a sporadic but potential threat to coconut production mi the region appear to belong to a globally important group of diseases cause by different strains of phytoplasmas. Their probable 
relationship to lethal yellowing and similarly destructive diseases elsewhere (lethal disease and Cape St Paul Wilt - Africa; lethal yellowing-Central Amenica and the Caribbean) confirms the need to take them seriously, but experience also shows that where resistance can be identified it can be highly effective. Since coconuts evolved and were domesticated in the region where these diseases are now found, there must be a good prospects for not only finding new sources of resistance but also to control diseases within the region which may also be effective elsewhere in the world. In view of the fact that no phytoplasma disease has been transmitted by seed either experimentally or naturally these diseases should not pose a threat to the exchange of germplasm providing that the FAO/IBPGR guidelines are followed.

The Manado participant realised it is uinportant to confirm putative phytoplasma etiology by appropriate methods. Knowing what the problems are and how to identify them will open up new research possibilities such as systematic screening for resistance; assessing risks to regional collection. and movement of germplasm; assessing and limiting the threat to coconut production and the ecology of the region. These targets could be achieved by developing a regional disease research programme and seeking international donor support. Improved knowledge of these diseases, so that they may be better controlled, will strengthen collaborations between researchers of similar diseases. This would improve the flow of information on lethal diseases of coconut from researchers to extension staff and farmers.

However, until more research answers; become available farmers and farmer groups could adopt the following steps to deal with disease outbreaks; cut down trees when they cease production and replace these with underplanted. seedlings intercropped with locally acceptable crops such as coffee, banana, and fuit trees; convert coconut stems to timber or dispose of safely to eliminate insect pest breeding sites; take seedlings from selected palms that have either survived disease or are the high yielding blocks in endemic areas; be cautious when using untested germplasm (improved cultivars, hybrids, etc) until their reaction to the disease is known.

\section{ACKNOWLEDGEMENT}

The sponsorship and support of IRA-Rothamsted, NRI-Chatham, BuroTrop, Balitka and APCC is gratefully acknowledged. The ideas expressed owe very much to the original research carried out by the Coconut Industry Board, Jamaica. 


\section{REFERENCES}

Ashburner, G.R. \& Been, B.O. (1997) Characterization of resistance to lethal yellowing in Cocos nucifera and implications of genetic improvement of this species in the Caribbean region. In: S.J. Eden-Green \& F. Ofori (eds) Proceedings of an International Workshop on Lethal Yellowing-like Diseases of Coconut, Elmina, Ghana, November 1995. Chatham, UK: NRI.

Chiarappa, L. (1979) The probable origin of lethal yellowing and its co-identity with other lethal disease of coconut. Fifth Session of the FAO Technical Working Parry on Coconut Production, Protection \& Processing, Manila, Philippines 3-8 December 1979.

Child, R. (1979) Coconuts, Longman, London (second edition).

Harries, H.C. (1978a) The evolution, dissemination. and classification of Cocos nucifera Botanical Review 44, 265-320.

Harries, H. C. (1978b) Lethal yellowing disease of coconuts in global perspective. Phil. Coconut Studies 3, 1-4

Harries, H.C. (1980) Malayan coconuts in the Caribbean: Caribbean coconuts in Malaysia. Proc. Int. Conf. Cocoa \& Coconuts, Kuala Lumpur, Malaysia (1978) 508-510

Harries, H.C. (1995) The genetics of durable resistance to lethal yellowing disease. In: C. Oropeza et al (eds) Lethal Yellowing: Research \& Practical Aspects pp. 149-171. Kluwer Academic Publishers.

Johnston, A (1961) Notes on coconut diseases of obscure origin. FAO Information Newsletter for Asia and the Far East (No. 3, 2nd ed.).

Maramorosch, K (1964) A survey of coconut diseases of unknown etiology. FAO, Rome.

Sharples, A (1928) Pahn diseases in Malaya. Malay agric. J 16, 313-360

Smith, A.C. (1932) San Blas coconuts in Malaya. Malay agric. J. 20,583-585

Smith, R.W. (1971). In: Coconut Breeding 1971, Yearly Progress Report Coconut Breeders' Consultative Committee, FAO, Rome.

Vanialingam, T., Khoo, K.T. \& Chew, P.S. (1975). Early performance of the Malayan Dwarf Yellow x West African Tall hybrid coconuts in Peninsular Malaysia. Oleagineux 30, 507-516. 